\title{
Szakemberhiány vizsgálata és feltételezett okai az építőiparban
}

\author{
R. SZTÁNYI \\ Debreceni Egyetem Műszaki Kar, Műszaki Menedzsment és Vállalkozási Tanszék, sztanyir@eng.unideb.hu
}

\begin{abstract}
Absztrakt. A munkaadók 36 \%-a küzd a megfelelő munkaerō megtalálásával világszerte. Magyarország építőipari cégeinek helyzetét bemutatva megállapítható, hogy a megszűnő vállalkozások száma az építőiparban 2013-ra az előző évhez viszonyítva 50\% felé emelkedett, amely tendencia 2014-ben tovább folytatódott. A szakmunkások közül sokan nem tudnak elhelyezkedni a hiányszakmának minösített szakmájukban, de sokan közülük nem is akarnak. Tanulmányom célja, hogy megvizsgáljam az építőiparban fennálló szakemberhiányt, illetve feltárjam ennek lehetséges, feltételezett okait.
\end{abstract}

\section{Bevezetés}

A hiányszakma kifejezés az elmúlt néhány év alatt rendkívül nagy szerepet kapott a szakképzés kapcsán. Ha egy korábban csak ritkán használt kifejezés hirtelen kulcsszerepet kap és gyorsan elterjed, annak komoly okai vannak. Ezeknek az okoknak két típusát különböztetjük meg. Az egyik lehetséges ok, hogy a korábban használt fogalmaknál aktuálisabbak, alkalmasabbak a kialakult helyzet vagy a felmerülő problémák leírásához, azok megértéséhez és kezeléséhez. Ilyen fogalmak például a kompetencia, az egész életen át tartó tanulás és a szakember/szakmunkáshiány vagy a hiányszakma. Utóbbi jelentése a 2007-es év második felétől megkettőződött, azaz ettől kezdve kétféle hiányszakmát különböztethetünk meg. 2007 nyarán elfogadták a térségi integrált szakképző központok (TISZK) gyors megalakulásához vezető közoktatási törtvény módosítást. A módosítás magába foglalta, hogy ahhoz, hogy a térségi integrált szakképző központok középtávon létszükségletet jelentő fejlesztési forrásokhoz jussanak, el kell fogadniuk a beiskolázás irányairól és arányairól szóló RFKB (Regionális Képzési és Fejlesztési Bizottságok) döntéseket. Ezek a döntések, melyeket „irány-arány” döntéseknek is nevezünk, három kategóriában különítik el a szakmákat. Megkülönböztetik a kiemelten támogatott (korlátlan beiskolázási keretszámú), támogatott (a megelőző év szintjén beiskolázható) és nem támogatott (csökkentett beiskolázási keretszámú) szakmákat. A kiemelten támogatott szakmák jelentik a köznyelvben a hiányszakmákat. Ezek számára nincs előzetes korlátozás vagy irányszám. [5.] Tanulmányom célja, hogy megvizsgáljam az építőiparban fennálló szakemberhiányt, illetve feltárjam ennek lehetséges, feltételezett okait.

\section{Az építőipar helyzete}

Az építőipari termelés 2013-ban elkezdődött növekedése 2014-ben is folytatódott több évig tartó visszaesés után. 2014-ben a termelés az egy évvel korábbinál 14,2 \%-al volt magasabb. Ennek 
következtében a termelés az ezredfordulón mért szintet meghaladta az iparágban, azonban a még közel negyedével elmaradt a válság előtti 2005-2006-os évek eredményeitől. Az épületek építésének számának növekedése összefüggésben áll a lakásépítések és ipari beruházások növekedésével, míg az egyéb építmények építésének számának növekedése az út- és vasútfejlesztések számának növekedésével mutat szoros kapcsolatot.

Székhely vizsgálatai alapján megállapította, hogy minden régióban emelkedett az odatartozó szervezetek termelése. 2014-ben azonban az év során újonnan kötött szerződések száma jelentős csökkenést mutatott a 2013-as évhez képest, 17 \%-al volt kisebb az előző évinél, illetve az éves termelésnek csupán 35\%-t tette ki. Azon építőipari vállalkozások esetén, ahol legalább 5 fôt foglalkoztatnak az alkalmazásban állók száma 1,7 \%-al emelkedett. Az építőipari átlagkeresetek továbbra is jelentősen elmaradnak a nemzetgazdasági átlagtól (csaknem negyedével a nemzetgazdasági átlag alatt maradtak). [3.]

\section{Az építőiparban foglalkoztatottak száma és szakemberek hiánya}

Magyarország építőipari cégeinek helyzetét bemutatva megállapítható, hogy a megszűnő vállalkozások száma az építőiparban 2013-ra az előző évhez viszonyítva 50\% felé emelkedett, amely tendencia 2014-ben tovább folytatódott. Ez, illetve a már említett nemzetgazdasági átlagtól elmaradó átlagkeresetek maguk után vonják, hogy számos a munkaképes szakmunkások kivándoroltak Magyarországról. Ezáltal szakember hiány alakult ki, melyet a foglalkoztatottság alakulása is szemléltet.

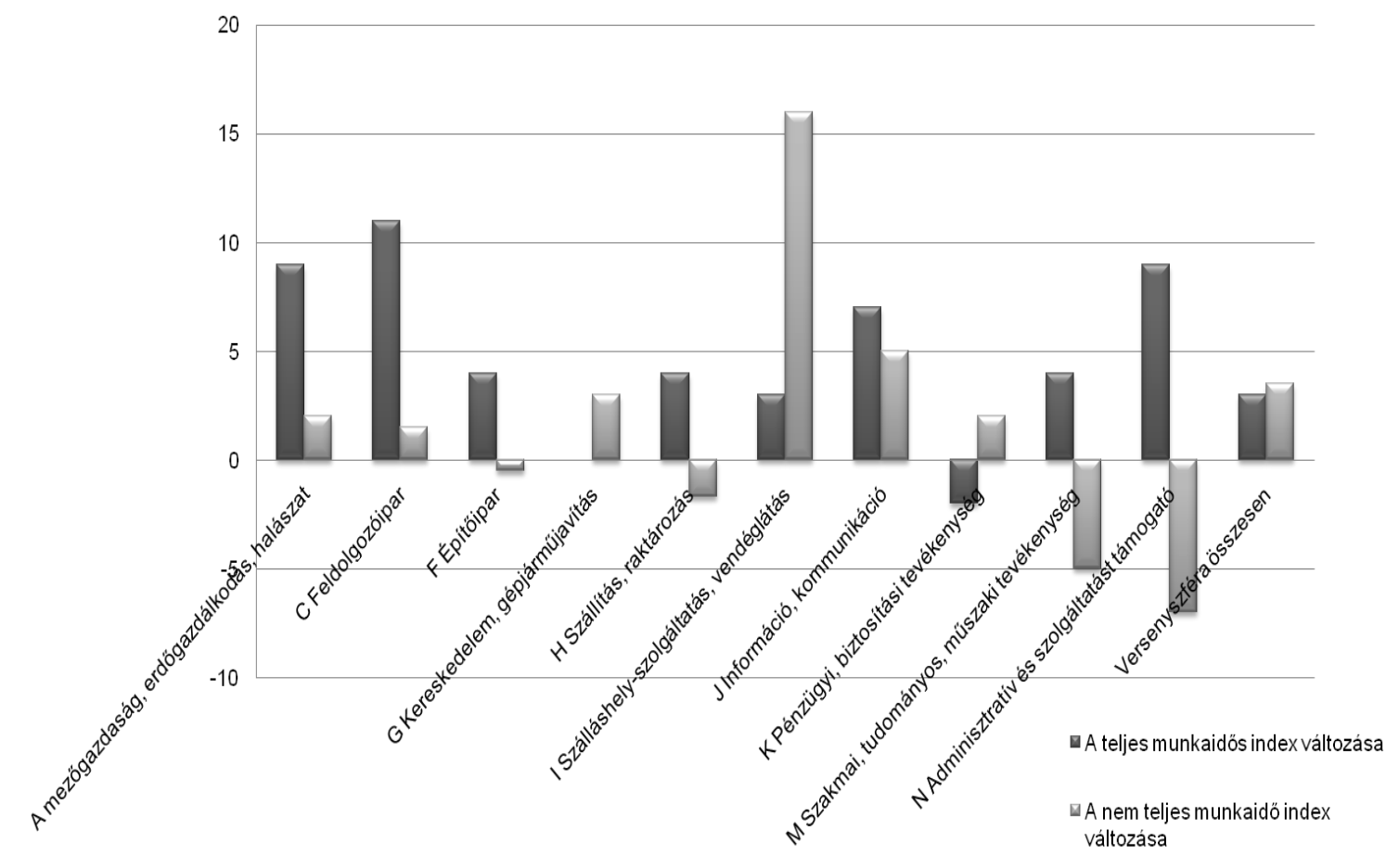

1. ábra: A teljes és nem teljes munkaidős foglalkoztatottak létszámának változása a versenyszféra föbb ágazataiban, 2014 I. negyedév

(Forrás: [4.]) 
Az 1. ábra a versenyszféra főbb ágazataira lebontva mutatja be a teljes és nem teljes munkaidős foglalkoztatottak számát. Amint látható a pénzügyi és biztosítási ágazat mellett az építőiparban foglalkoztattak száma rendkívül alacsony.

A szakemberek számának alakulását és hiányát, illetve ennek okait a ManpowerGroup vizsgálja 42 országban. A kutatásukban megállapították, hogy a munkaadók 36 \%-a küzd a megfelelő munkaerő megtalálásával világszerte. Ezt mutatja a felmérés azon része is, amelyben meghatározták azoknak a cégeknek a pontos arányát, amelyek toborzáskor nehézségekkel találják szembe magukat. Ez az érték az előző évhez képest $1 \%$-al emelkedett. A felmérés szerint Japánben mutatható ki a legmagasabb érték, miszerint a munkaadók 81 \%-a küzd nehézségekkel az alkalmazott kereséskor. Szintén a felállított lista elején szerepel világszinten Peru (67\%) és India (64\%), az EMEA ${ }^{1}$ régióban pedig Törökország (63\%), Izrael (49\%) és Magyarország (45\%). A legalacsonyabb érték a Finneknél jelentkezik (2\%). [4.]

Magyarországon 2014-ben a legnehezebben betölthető munkakörök a következők:

- Szakmunkás

- Csoportvezető

- Mérnök

- Sofőr

- Vendéglátó ipari dolgozó

- Orvos

- Értékesítő

- Könyvelő és pénzügyi szakember

- Gépkezelő

- Informatikus

Magyarországon azoknak a cégeknek a száma, amelyek szakmunkás munkaerőhiánnyal küzdenek a globális átlagtól jóval magasabb és folyamatosan növekszik. [4.]

\section{A kínálat és a kereslet becslésének alapelvei és feltételezései}

Ahhoz, hogy a szakemberhiány mértéke megállapítható legyen az építőiparban meg kell vizsgálni a kereslet és kínálat viszonyát. Fazekas et.al. (2009) kutatásában megyénként és régióként előrebecslést készített a szakmunka iránti keresletre és a szakmunkás- kibocsátásra szakmánként ahhoz, hogy összehasonlítsa a szakképző iskolák kibocsátását és a várható munkaerőpiaci keresletet. A várható szakmunkás kibocsátás becslésének alapját a 2008/2009-es tanév 11. évfolyamaira belépők megyénkénti és szakmánkénti bontású adatai jelentették. A várható kereslet becslésének alapját pedig egy elvégzett adatfelvétel tisztított, súlyozott és teljeskörűsített vállalati adatainak aggregálása adta. A várható adatokat, amelyek a létszámnövelésre és -csökkentésre vonatkoznak szakmánként, illetve megyénként és régiónként összegezték. Ezen várható keresleti és kínálati adatokból a kereslet és

\footnotetext{
${ }^{1}$ Európa, a Közel-Kelet és Afrika
} 
kínálat közötti várható eltérést állapították meg szakma, illetve megye és régió szerinti bontásban. Az elvégzett számítások és a kapott értékek a korábban elvégzett erre vonatkozó vizsgálatoktól eltért. Ugyanis nem csupán a szakiskolai várható kibocsátást vetették össze a várható kereslettel hogy a kereslet és kínálat eltérésének számításakor, hanem kiszámították azt is, hogy a a várható szakiskolai kibocsátás mekkora hányada fog ténylegesen a végzettség szerinti szakmájában elhelyezkedni. [2.]

\subsection{A kínálat és a kereslet becslése - összefoglaló adatok}

Az 1. táblázat az országos, szakmánkénti szakiskolai kibocsátásra vonatkozó előrejelzéseket mutatja be a megfelelő munkaerő-piaci keresleti adatokkal párhuzamosan, amely alapján a kereslet és kínálat eltéréseit is láthatjuk. A táblázatban szereplő adatok olyan illusztratív adatok, amelyek a lokális munkaerőpiacokon érvényes keresleti és kínálati helyzet elemzésének alapján képezik. Ennek egyik oka, hogy a táblázatban a keresleti és kínálati oldalon is becsült adatok szerepelnek, nem pedig az adott szakmában a jövőben a lokális munkaerőpiacra ténylegesen kilépők számát és az ugyanott ténylegesen foglalkoztatottak számát szemléltető adatok. A másik oka, hogy a táblázatban országosan aggregált adatok szerepelnek, amelyek éppen az amúgy ténylegesen múködő lokális munkaerőpiacok kínálati és keresleti viszonyait és különbségeit takarják el. Harmadik ok pedig, hogy a keresleti oldalon nem szerepel az egyik legfontosabb pareméter, a kínált bérek. [2.]

\begin{tabular}{|c|c|c|c|c|c|c|}
\hline \multirow[b]{2}{*}{$\begin{array}{l}\text { Képzések } \\
\text { nevei }\end{array}$} & \multicolumn{2}{|l|}{ Kínálat } & \multicolumn{2}{|l|}{ Kereslet } & \multicolumn{2}{|l|}{ Eltérés } \\
\hline & $\begin{array}{l}\text { Beiskolázás } \\
\text { szakiskola } \\
\text { és } \\
\text { szakközépi } \\
\text { s-kola } \\
\text { szakképző } \\
\text { évfolyamár } \\
\text { a 2010/11 } \\
\text { (fö, } \\
\text { becslés) }\end{array}$ & $\begin{array}{l}\text { Kilépés } \\
\text { szakiskolá- } \\
\text { ból és } \\
\text { szakközép- } \\
\text { iskolából } \\
2012 / 13 \\
\text { (fő, becslés) }\end{array}$ & $\begin{array}{l}\text { Saját } \\
\text { szakmában } 8 \\
\text { hónapon } \\
\text { belül } \\
\text { elhelyezke- } \\
\text { dők száma } \\
\text { (fó, becslés) }\end{array}$ & $\begin{array}{l}\text { Vállalkozá- } \\
\text { sok } \\
\text { kereslete } \\
\text { 2012/13 (fö, } \\
\text { becslés) }\end{array}$ & $\begin{array}{l}\text { Szakiskolai } \\
\text { kibocsátás } \\
\text { és kereslet } \\
\text { 2012/13-as } \\
\text { országos } \\
\text { szakmán- } \\
\text { kénti } \\
\text { eltérése } \\
\text { (becslés) }\end{array}$ & $\begin{array}{l}\text { Munkaerő- } \\
\text { kínálat és } \\
\text { kereslet } \\
2012 / 13 \text {-as } \\
\text { országos } \\
\text { szakmán- } \\
\text { kénti } \\
\text { eltérése } \\
\text { (becslés) }\end{array}$ \\
\hline Kőműves & 1436 & 1279 & 393 & 246 & 1033 & 147 \\
\hline $\begin{array}{l}\text { Festő, } \\
\text { mázoló, } \\
\text { tapétázó }\end{array}$ & 1124 & 1001 & 308 & 79 & 923 & 229 \\
\hline Burkoló & 254 & 316 & 97 & 40 & 355 & 137 \\
\hline $\begin{array}{l}\text { Épület- } \\
\text { asztalos }\end{array}$ & 307 & 274 & 67 & 64 & 209 & 3 \\
\hline $\begin{array}{l}\text { Ács, } \\
\text { állványozó }\end{array}$ & 305 & 272 & 84 & 153 & 119 & 70 \\
\hline $\begin{array}{l}\text { Szerkezet- } \\
\text { lakatos }\end{array}$ & 608 & 541 & 179 & 476 & 66 & 297 \\
\hline $\begin{array}{l}\text { Villany- } \\
\text { szerelő }\end{array}$ & 721 & 642 & 122 & 592 & 50 & 470 \\
\hline
\end{tabular}




\begin{tabular}{|l|l|l|l|l|l|l|}
\hline Bádogos & 53 & 47 & 14 & 41 & 6 & 27 \\
\hline
\end{tabular}

1. táblázat: Becsült kínálat és kereslet az építőipart érintő képzettségek szerint (fö - országosan)

(Forrás: [2.])

A táblázatban szereplő adatok alapján megállapítható, hogy az országosan jelenlévő „trendek” fennmaradása esetén túlkeresletre lehet számítani a jövőben is, azaz a szakmunkás kibocsátás mértéke túl alacsony lesz. [2.]

\subsection{A kereslet változása és a várható létszámváltozás az elkövetkező években}

A szakképzett munkaerő iránti kereslet növekedése az elkövetkező négy éves távlatban a Pest megyei és a budapesti vállalkozások közében várható, a prognosztizált létszámnövekedés 9601 fö, illetve 9 248 fő. Tolna megyében várható a legkisebb mértékű növekedés (95 fó). A régiókat tekintve a legnagyobb mértékű növekedés Közép-Magyarországon várható az elkövetkező években (kb. 18850 fő az 5. évre), a legkisebb mértékű növekedés Dél-Dunántúlon várható (kb. 538 fő az 5. évre). A többi régió esetében a várható létszámnövekedés közel azonos. A külföldi tulajdoni hányadot tekintve a legnagyobb mértékű várható létszámnövekedést a tisztán hazai (9 185 fő), illetve a tisztán külföldi tulajdonú (20580 fó) cégek jelezték. Az éves nettó árbevételt tekintve a legnagyobb méretű létszámbővítést az az egymilliárd forint feletti bevétellel rendelkező vállatok fogják végrehajtani az 5. évre (24869 fő). Az 500 millió és egy milliárd forint közötti árbevételű vállalatoknál 1975 fő létszámbővítés várható országos szinten. Az ágazatok szerinti megoszlást tekintve a szakképzett munkaerő iránti kereslet legnagyobb arányú bővítését az ipari (10 619 fó) és szolgáltató cégek (19 144 fő) tervezik, míg a legkisebb arányú bővítést a mezőgazdasági cégek (134fő).

Emellett az is látható, hogy a vállalkozások jelentősen lecsökkentenék a 4 éven túli munkaerő-keresleti előrejelzéseiket. Ez a csökkenés minden szektort érint (akárcsak 12 hónapos időtávon) de lényegesen kisebb a visszaesés mértéke. Ebből arra következtethetünk, hogy a gazdasági várakozások vissza kívánnak térni a válság előtti munkaerő-felvételi szokásaikhoz hosszabb távon, de ez a hatás nem teljes. [2.]

\section{A vállalatok elégedettsége a szakképzett pályakezdők kompetenciáival}

A kereslet és a kínálat kvantitatív illeszkedése mellett további fontos szempont, hogy a szakemberek kompetenciái és tudása illeszkedjen a vállalatok minőségi elvárásaihoz. A vállalatok mind általános készségek tekintetében, mind pedig szakmai tudás tekintetében elégedettebbek az érettségivel rendelkező szakmunkás pályakezdők tudásával. A legnagyobb problémát négy kompetencia/ismeret hiánya jelenti a szakemberek esetében, melyek a gazdasági ismeretek, a vezetési és szervezetési képességek, a számítógép ismeretek és az idegennyelv-tudás. Emellett a szakmai-gyakorlati jártasság is megjelenik, mint érzékelhető hiány a szakemberek körében, mellyel a vállalatok különösen az érettségivel rendelkező szakmunkások esetében elégedetlenek. Ha az átlagos képességeket, készségeket tekintjük ágazati szektor szerinti megoszlásban, akkor az érettségivel nem rendelkező szakmunkások esetében nincsenek lényeges eltérések, míg az érettségivel rendelkező szakmunkások 
esetén a mezőgazdaságban valamelyest magasabb az általános készségekkel való elégedettség megítélése, mint a többi szektorban. [2.]

\section{A szakemberhiány feltételezett okai az építőiparban}

A szakemberhiánynak az esetükben hiányzó kompetenciákon kívül számos oka lehet. A szakmunkások közül sokan nem tudnak elhelyezkedni a hiányszakmának minősített szakmájukban, de sokan közülük nem is akarnak. Ennek egyik lehetséges oka, hogy a továbbtanulást választják a hosszabb távú előnyök és a magasabb fizetés reményében. Szórványosan ugyan előfordulnak kiemelt jövedelmek, de a végzés előtt állók átlagos bérvárakozása csak a reálisnak mondható 105 ezer forint körül van, a szakmák között jelentős szóródással. A legmagasabb jövedelmet olyan szakmákban végzős diákok várják, amelyekben alacsonyabb a legális munkaviszonyban való elhelyezkedés esélye (kőműves, hegesztő ezekben a legmagasabb a fekete munka aránya). Az asztalos szakmában nagyon rossznak ítélik a jövedelmi kilátásokat a munkavállalók. Azonban a munkáltatói szférának a bérkínálatban nincs nagy mozgástere. Főként a hazai tulajdonú kis- és középvállalatok elégedetlenek, akik kevéssé versenyképesek és céljuk, hogy minél olcsóbb szakember utánpótlást találjanak, és ennek érdekében az alacsony árért akár még a minőségi elvárásokból is hajlandóak alább adni. Viszont a versenyképességük nem biztosított azáltal, hogy olcsó és magas színvonalú munkát ellátni nem képes szakmunkást alkalmaznak. Ezáltal sem a szakmunkás, sem pedig a vállalat perspektívája nem javul.

\begin{tabular}{llll}
\hline Ország & $\begin{array}{l}\text { Havi átlagkereset } \\
\text { (USD) }\end{array}$ & Heti óraszám & $\begin{array}{l}\text { Órabér } \\
\text { (USD) }\end{array}$ \\
\hline Egyesült Királyság & 2703 & 43,2 & 15,64 \\
\hline Ausztria & 2432 & 35,5 & 17,13 \\
Svájc & 2284 & 41 & 13,93 \\
Németország & 2018 & 39 & 12,94 \\
\hline Belgium & 1993 & - & - \\
\hline Hollandia & 1911 & 39,5 & 12,09 \\
\hline Franciaország & 1773 & 37,1 & 11,92 \\
\hline Csehország & 815 & - & - \\
\hline Magyarország & 642 & 43 & 3,73 \\
\hline Románia & 379 & 43 & 2,2 \\
\hline 2. táblázat: Szakmunkások havi átlagkeresete és órabére az építóiparban az Európai Unió néhány országában
\end{tabular}

(Forrás: [1.])

A 2. táblázat mutatja be a szakmunlások havi átlagkeresetét és órabérét az építőiparban az EU néhány országában. A táblázatból kitűnik, hogy Magyarországon a havi átlagkereset az EU-s országokéhoz képest jóval alacsonyabb, illetve a heti óraszám magasabb.

További lehetséges ok az iparágban jellemző, átlagosnál nehezebb munkakörülmények. Az építőipari szakmák fizikailag is megerőltetőek, ezt sokan igyekeznek elkerülni a magas jövedelmezőség ellenére 
is. Az építőiparhoz kapcsolódó szakmunkák többsége idénymunka, így a szakmunkások iránti kereslet sem egyenletes az év minden hónapjában és a fizetések sem. Akik télen is találnak munkát maguknak azoknak az időjárási körülmények megnehezítik a munkavégzést és csökkentik a munkavállalási kedvet is. Az építőiparban nem csak az idénymunka jellege veszi el a szakmunkásoktól a munkavállalói kedvet, hanem a fekete munka elterjedése is, amely ráadásul többletjövedelmet nem jelent, csupán kiszolgáltatottabb státuszt. [5.] A nem megfelelő munkakörülmények stresszorként jelentkezhetnek a munkavállalók esetében, amely kihathat a teljesítményükre is. Ilyen például a hatékony, biztonságos és gyors munkát lehetővé tevő eszközök hiánya, ha az egyénnek nincs beleszólása abba, miként végzi a munkáját, milyen eszközöket használ, milyen ütemezéssel dolgozik vagy ha veszélyes körülmények között kell dolgoznia. [7.]

A munkaerőhiány további okaként említhetők a mobilitási tervek. Ha a munkaerő kereslet és kínálat nem egy településen vagy térségben található, akkor az megnehezíti a napi kapcsolattartást a családdal, több órás utazással érik el a munkahelyüket. Ez mind fizikailag, mind szellemileg megterhelő a munkavállalók részére, illetve az utazási költségeket nagy részük nem tudja biztosítani, ami szintén okozza a munkaerő elvándorlást, ezáltal a szakemberhiányt. [5.]

\section{Javaslatok}

A munkavállalók részéről javasolnám karrier - SWOT elkészítését. Ahhoz, hogy a szakmunkások eladhatóvá tegyék képességeiket, szükségük van belső erősségeik (S), gyengeségeik (W) és külső lehetőségeik (O) és veszélyeik (T) ismeretére. A karrier - SWOT elkészítésének sablonját a következő ábra szemlélteti.

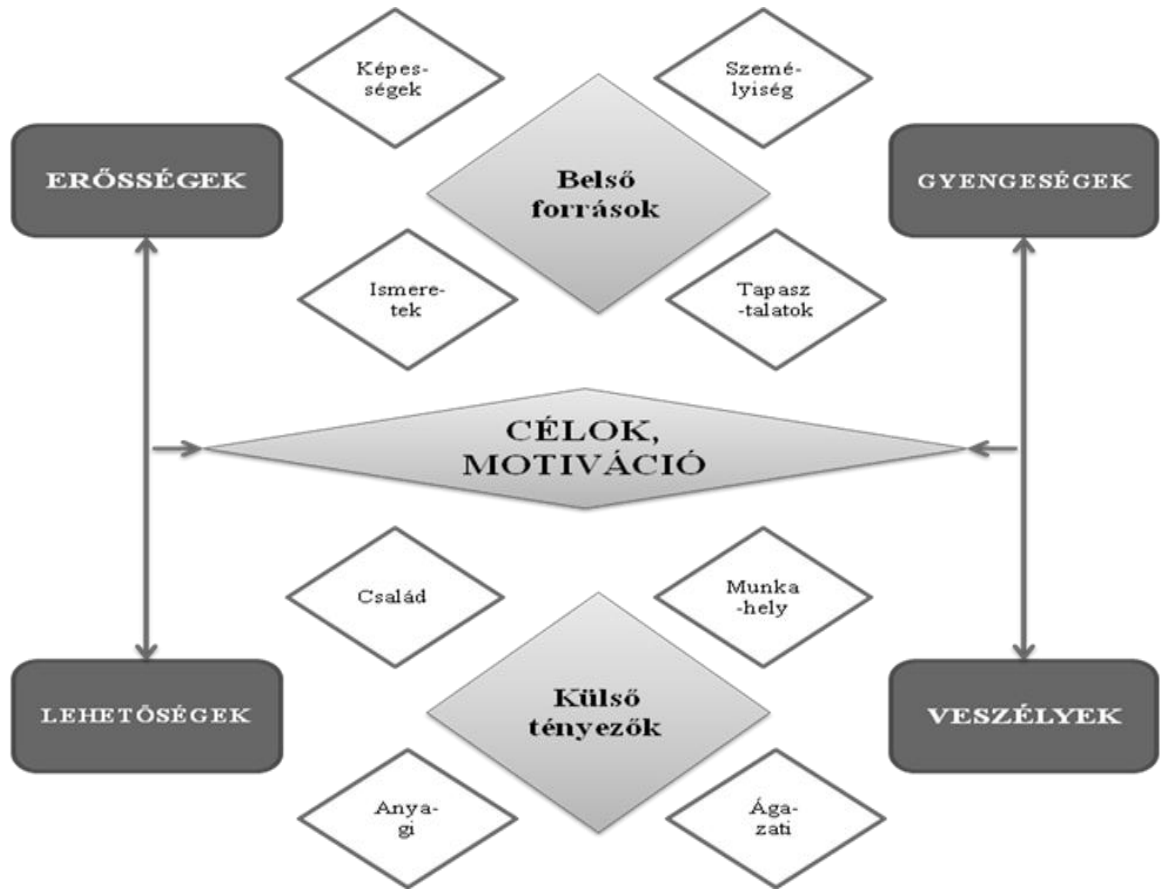

2. ábra: Karrier - SWOT

(Forrás: [6.]) 
A 2. ábra mutatja be a karrier - SWOT pontjait. Amint látható az egyén céljai és motiváció meghatározása után erre felépítve határozhatja meg az erősségeit, gyengeségeit, lehetőségeit és veszélyeket. A belső források esetében olyan tényezőket kell figyelembe vennie, mint a képességek, személyiség, ismeretek és tapasztalatok. A külső tényezők esetében a család, a munkahely, az anyagi szempontok és az ágazati sajátosságok játsszák a legfontosabb szerepet. Annak érdekében, hogy sikeresekké váljunk, elengedhetetlen, hogy egy működő folyamat rendszereként szemléljük tevékenységünket. [6.]

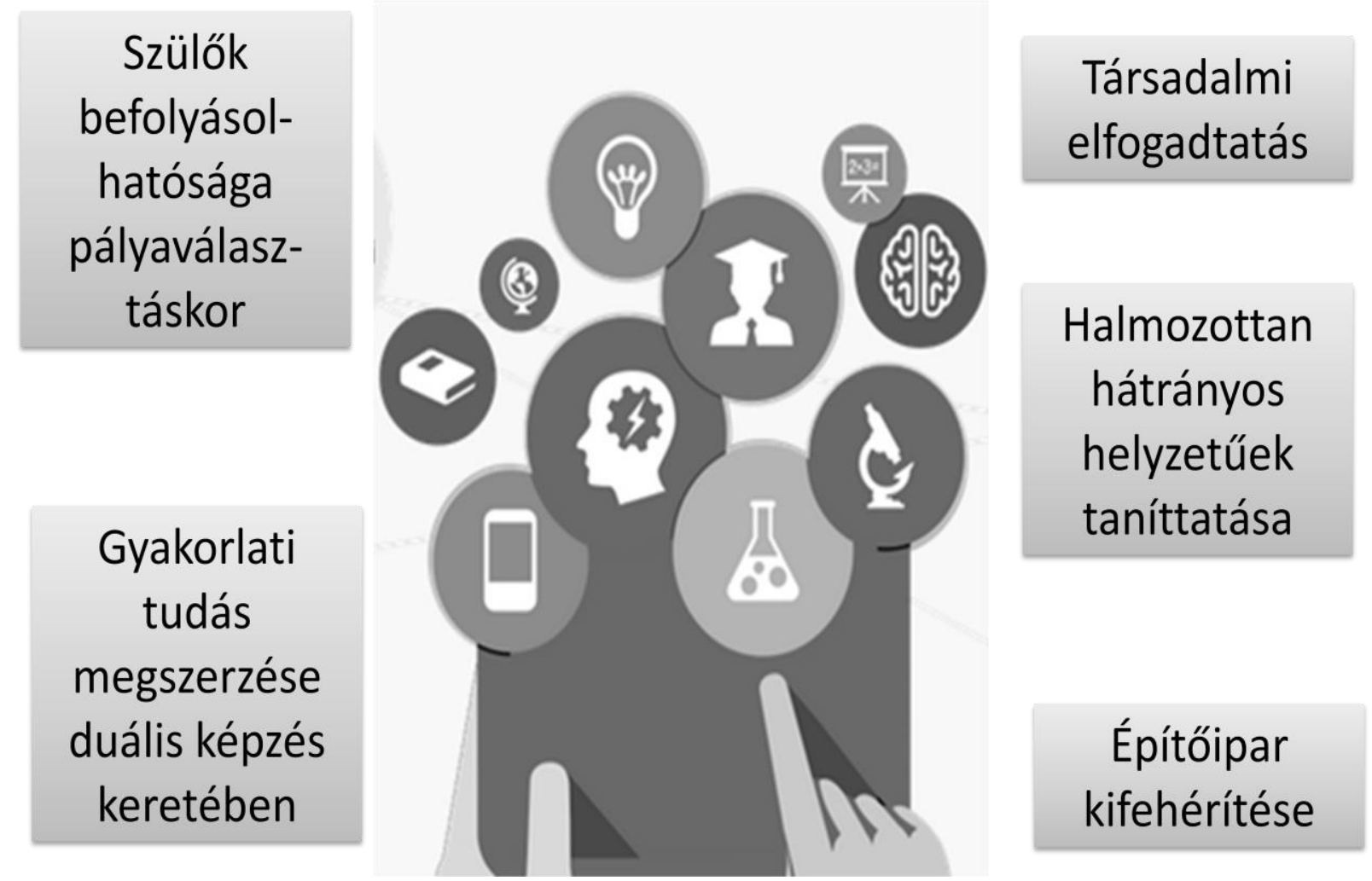

3. ábra: Javaslatok a szakemberhiány mérséklésére az épitőiparban

(Forrás: Saját szerkesztés)

A 3. ábra szemlélteti további javaslataimat a szakemberhiány mérséklésére vagy akár minimalizálására az építőiparban. Az első javaslatom, hogy a pályaválasztáskor ne csak a pályaválasztás előtt álló korosztályt célozzák meg az egyes szakképző intézmények, hanem a szülőket is. Ugyanis a tapasztalatok azt mutatják, hogy a pályaválasztás előtt álló fiatalok az esetek döntő többségében nem önállóan, hanem szülői vélemény kérésével hozzák meg döntésüket. Ezáltal a szülők megcélzását javasolnám pályaválasztás előtt.

Következő javaslatom a duális képzés bevezetése a szakmunkás képzésben is, amely lehetővé tenné a gyakorlati tudás elmélyítését és megszerzését ipari körülmények között a gyakorlati helyszínt szolgáltató cégek keretein belül, míg az elméleti oktatás továbbra is az iskolákban folyna az ipari igényeknek megfelelve.

A további javaslatim között szerepel a szakmunka társadalmi elfogadtatása, ugyanis ha a társadalomban jobban elfogadottabbá válna és felértékelődne a szakmunka, akkor véleményem szerint többen választanák azokat. Emellett fontosnak tartanám az építőipar kifehérítését, így több 
ember számára válnának vonzóbbá az építőipari szakmák. Illetve a halmozottan hátrányos helyzetűek taníttatása és építőiparban való foglalkoztatása is számos előnyt jelente mind az építőipar, mind pedig a társadalom számára.

\section{Összefoglalás}

Az utóbbi években a Magyarországi építőiparban számos változás következett be, amelyek kedvezőtlenül hatnak rá. Ennek okai közt említhetők a kialakult szakemberhiány, az építőipari munka presztízse és a megfelelően képzett munkaerő hiánya.

Tanulmányomban elemeztem az építőipar jelenlegi helyzetét, különösképpen a fennálló szakemberhiányt, illetve feltártam ennek okait, melyek között említhetők a kompetenciahiány, a továbbtanulás előnyben részesítése, az idénymunka, a nehéz munkakörülmények és az ingázás.

Javaslatokat fogalmaztam meg ezen okok kiküszöbölésére és a munkaerőhiány csökkentésére az építőiparban, melyek közül eredményesek lehetnek a karrier SWOT felvázolása a munkavállalók esetében, a szülők megcélzása pályaválasztáskor, a duális képzés, mint a gyakorlati tudás elmélyítésének lehetősége, a halmozottan hátrányos helyzetűek bevonása a szakképzésbe, a társadalmi elfogadtatás és az építőipar kifehérítése.

\section{Hivatkozások}

[1] ec.europa.eu http://ec.europa.eu/eurostat/statistics-explained/index.php/Wages_and_labour_costs/hu

[2] Fazekas et.al. (2009), A munkaerő-piaci szereplők az iskolarendszerü szakképzés beiskolázási szerkezetének kialakításában, Magyar Kereskedelmi és Iparkamara

[3] KSH A (2015), Jelentés az építőipar 2014. évi teljesítményéről

[4] KSH B (2014), Statisztikai tükör, Munkaerő-piaci folyamatok, 2014. I. negyedév

[5] Gy. Mártonfi (2011), Hiányszakmák, In: Educatio 2011/3 p. 374-386.

[6] A. E. Matkó (2014), Önmenedzselés [elektronikus dokumentum], DEBRECENI MÚSZAKI KÖZLEMÉNYEK 13:(2) p.

[7] E. Szűcs, S. Kovács, E. Tornai, T. Takács, A. Matkó (2014), A munkahelyi stressz vizsgálata, TÁRSADALOMKUTATÁS 32:(4) pp. 384-401. 